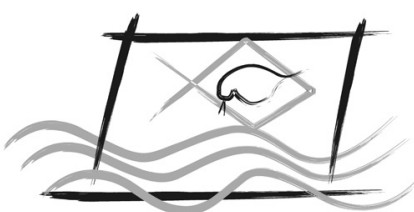

ECOTOX - BRASIL

\title{
Effects of diesel oil and environmental quality on the enzymatic activities of a tropical estuarine catfish and implications for contamination assessment
}

\author{
Berenger, J.N. ${ }^{1}$, Moraes, J.C. ${ }^{2}$, Oliveira, M.M. ${ }^{3}$, Raimundo, J.M. ${ }^{4} \&$ Molisani, M.M. ${ }^{2}$ \\ ${ }^{1}$ Programa de Pós-Graduação em Ciências Ambientais e Conservação, UFRJ campus Macaé, Av. São José do Barreto 764, Barreto, Macaé \\ (RJ) CEP: 2795-045, Brazil \\ ${ }^{2}$ Núcleo em Ecologia e Desenvolvimento Sócio Ambiental de Macaé, Universidade Federal do Rio de Janeiro (NUPEM/UFRJ), Av. São \\ José do Barreto 764, Barreto, Macaé (RJ) CEP: 2795-045, Brazil \\ ${ }^{3}$ Laboratório de Ecotoxicologia e Microbiologia Ambiental (LEMAM), Instituto Federal de Educação, Ciência e Tecnologia Fluminense \\ (IFFluminense), campus Cabo Frio/RJ, Estrada Cabo Frio - Búzios s/n, Cabo Frio, CEP 28909-971, Brazil
}

${ }^{4}$ Universidade Federal do Rio de Janeiro, Campus Macaé, Av. Aloízio da Silva Gomes 50, Novo Cavaleiros, Macaé (RJ), CEP. $27930-$ 560, Brazil

(Received June 22, 2017; Accept September 24, 2017)

\begin{abstract}
The contamination of coastal areas by petroleum and its derivatives is a relevant issue based on large-scale production and consumption. This study presents field and laboratory surveys on the detoxification enzymes on the estuarine/coastal catfish Genidens genidens to understand the enzymatic responses to oil derivatives and environmental conditions. Field catalase (CAT) and glutathione S-tranferase (GST) measurements suggest oxidative stress and acting repair mechanisms in fishes, but were not induced by diesel oil as indicated by laboratory studies. On the other hand, higher ethoxyresorufin-O-deethylase (EROD) activities following higher polycyclic aromatic hydrocarbon (PAH) concentrations in the estuarine waters suggested fish responsiveness to oil contamination, mainly due to the fact that such EROD values were similar to the magnitude measured in fish during a 24-h exposure to diesel oil in the laboratory. However, other environmental estuarine conditions may also act on field EROD activities since PAHs concentrations in the water-soluble fraction of diesel oil (WSFDO) were higher than those measured in estuarine waters.
\end{abstract}

Keywords: Biomarkers, Cytochrome P450, Neotropical fish, Polycyclic aromatic hydrocarbon, Estuary

\section{INTRODUCTION}

The contamination of coastal waters by petroleum and its derivatives is an important issue due to largescale offshore and inshore exploration and socioeconomic consumption (NRC, 2003). In estuaries and coasts, spills of different intensities, but generally of a short duration (Meniconi et al., 2002) raise the question about how sublethal levels of compounds from oil derivatives could affect coastal organisms.
In this context, fish enzymatic activities have been employed as a monitoring tool regarding the presence of xenobiotics (Fonseca et al., 2011). Phase I and II biotransformation enzymes are involved in the metabolism of a number of pollutants, including oil derivatives and compounds, such as some forms of polycyclic aromatic hydrocarbon (PAHs) (Payne, 1976). Phase I reactions are mainly mediated by cytochrome P450 (CYP) enzymes, such as CYP1, and originate metabolites less or more actives than the parental compound. Phase II reactions comprise

*Corresponding author: Mauricio Mussi Molisani; e-mail: molisanimm@yahoo.com.br 
conjugations mediated by enzymes, such as uridine diphosphate glucuronosyltransferase (UGT) and glutathione S-transferase (GST) and usually result in inactive metabolites (Pathiratne \& Hemachandra, 2010). Due to their roles in the detoxification and activation of xenobiotics, alterations of the expression of CYP and phase-II enzymes are important from a toxicological point of view (van der Oost et al., 2003). The binding of polycyclic aromatic hydrocarbons (PAHs) and other pollutants to the aryl hydrocarbon receptor (AHR), a ligand dependent transcription factor, results in the induction of CYP1A, which is often measured in terms of 7-ethoxy-resorufin-O-deethylase (EROD) activity (Denison \& Nagy, 2003). In addition to biotransformation enzymes, the expression and activity of antioxidant enzymes may be altered by exposure to pollution. Chronic exposure to PAHs produces an increase in oxygen-derived free radicals, generating oxidative stress. Thus, antioxidant enzymes, such as catalase, are also used as monitoring biomarkers in fish (van der Oost et al., 2003).

In Brazil, many coastal and marine ecosystems are under pressure due to oil exploration and transportation. In many southeastern Brazil regions, coastal cities have grown due to the installation of operational bases to support offshore oil exploration, leading to increased urbanization, navigation, oil transportation and overall socioeconomic pressures (Molisani et al., 2013a). The municipality of Macaé is the main onshore operational basin for offshore oil exploration in Campos Basin, the largest oil reserve of the Brazilian continental shelf. Because of this, its coastal ecosystems, such as the Macaé River estuary and adjacent coast, already display a polluted status and adverse effects on biological resources (Molisani et al., 2013 a, b; Santiago et al., 2016). In this context, biotransformation and antioxidant enzymes could be used as biomarkers for determining the impact of oil derivatives, such as diesel oil, which is highly employed in local navigation, car traffic, and others. The catfish $G$. genidens (Cuvier, 1829) can be a useful tool for field and biological contamination assessments of oil pollution in this and others regions throughout the Brazilian coast. This specie is abundant in Brazilian estuaries and along the coast, and are usually described at the bottom of low depth and turbid waters, where the population feeds, reproduces and shelters, always supporting a wide range of salinity and temperature. Its diet is composed mainly by detritus, small fishes, decapods, polychaetes and bivalves. Adults are commonly reported in the open ocean but also colonize estuarine waters during reproduction, where juveniles remain until return to the open ocean as adults. (Mishima \& Tanji, 1981; Schmidt et al., 2008). The catfish $G$. genidens is a native species of the Macaé River estuary. Thus, the objectives of the present study were to evaluate CAT, GST and EROD activities in the liver of the estuarine/coastal fish Genidens genidens from the Macaé River estuary and compare the data to enzymatic conditions induced during experimental diesel oil exposure which provide implications for environmental and biological contamination assessment.

\section{MATERIALS AND METHODS}

\section{Sampling procedure and experimental protocol}

Fish sampling was carried out during six events between 2011 and 2012 at the outlet of the Macaé River estuary (Fig. 1). Twelve individuals were obtained during each sampling, sacrificed by medullar section and subsequently measured, weighted, and sexed. The liver was collected, frozen in liquid nitrogen and stored in the laboratory at $-80^{\circ} \mathrm{C}$ until analysis. This study involving animals was conducted in accordance with national and institutional guidelines for the protection of animal welfare.

For the laboratory toxicity test, forty fish were collected in September 2012 and acclimated for 15 days in four 100$\mathrm{L}$ tanks (ten individuals in each tank) containing filtrated, dechlorinated and UV sterilized waters with constant aeration, photoperiod, $\mathrm{pH}$ and dissolved oxygen levels. Fish were fed with commercial fish food at $48 \mathrm{~h}$-intervals and feeding was suspended prior to the beginning of the experiments. After the acclimation period, fishes were exposed to the water-soluble fraction of diesel oil (WSFDO) prepared according to Singer $e t$ al. (2000) and Nicodem et al. (1997). Diesel oil was obtained from a gas station and mixed with water at a 1:9 diesel/water ratio. The mixture was exposed to direct sunlight during 12 $\mathrm{h}$ and allowed to the rest for a further $12 \mathrm{~h}$, simulating the naturally occurring conditions of the estuary. The WSFDO was separated and diluted to $20 \%$ for the exposure assays. The test was carried out in the four 100-L glass tanks containing 10 fish each in the control (2 tanks) and exposure (2 tanks) tests, respectively. Fish were exposed to WSFDO for 6, 24, and $72 \mathrm{~h}$. For each time point, three fish were sampled in each tank and killed by medullar section. The liver was removed and stored at $-80^{\circ} \mathrm{C}$ until the enzymatic analyses. Water temperature, dissolved oxygen, $\mathrm{pH}$ and conductivity were continuously measured.

\section{Enzymatic biomarkers}

The livers were weighted, homogenized $(1: 4 \mathrm{w} / \mathrm{v})$ in potassium phosphate buffer $(0.1 \mathrm{M} ; \mathrm{pH} 7.0)$ containing sucrose

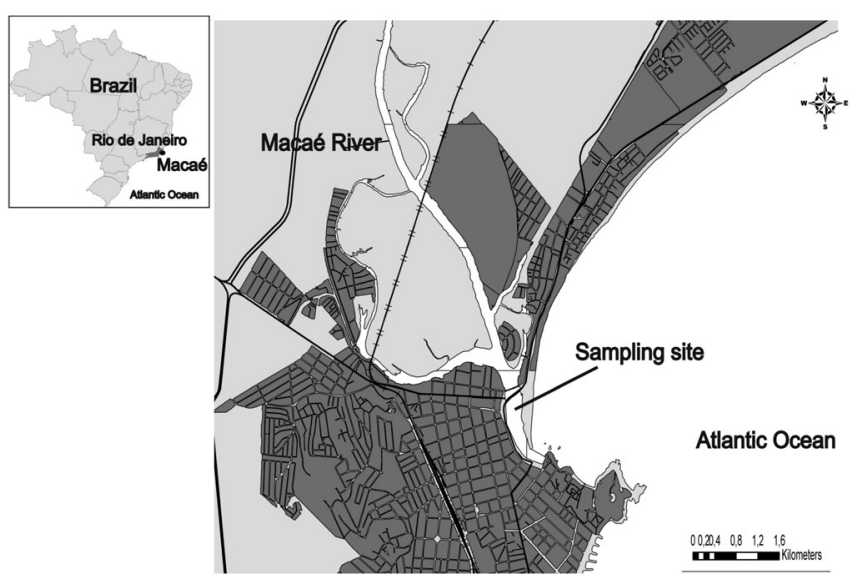

Fig. 1. Map of the study area and sampling site 
$0.25 \mathrm{~mol} \mathrm{~L}^{-1}$. The samples then centrifuged at $800 \mathrm{x} \mathrm{g}$ for 6 $\min$ at $4{ }^{\circ} \mathrm{C}$ and the supernatants separated for CAT analyses. An aliquot of this supernatant was centrifuged at 20,000 $\mathrm{x} g$ for $33 \mathrm{~min}$ at $4^{\circ} \mathrm{C}$. The supernatant obtained after this second centrifugation was once again centrifuged at $105,000 \mathrm{x}$ g for $90 \mathrm{~min}$ at $4^{\circ} \mathrm{C}$ and the pellet re-suspended in buffer for the EROD analyses while the supernatants were separated for the GST determinations (Cunha Bastos et al., 2004). CAT activity was determined at $240 \mathrm{~nm}$ following $\mathrm{H}_{2} \mathrm{O}_{2}$ decomposition according to method proposed by Aebi (1984). GST activity was determined by measuring the increase in absorbance at $340 \mathrm{~nm}$, incubating reduced glutathione (GSH) and 1-chloro-2, 4-dinithrobenzene (CDNB) as substrates (Keen et al., 1976). EROD activities were measured in the microssomal fraction of the liver based on the deethylation of 7-ethoxyresorufin (1 mmol L $\mathrm{L}^{-1}$ ), a reaction catalyzed by CYP in the presence of NADPH (25 $\left.\mathrm{mmol} \mathrm{L}^{-1}\right)$, and producing 7-hydroxyresorufin, which emits fluorescence at $582 \mathrm{~nm}$ when excited at $550 \mathrm{~nm}$ (Burke, 1985; Cunha Bastos et al., 2004). Protein levels were measured by the method reported by Bradford (1976) using bovine serum albumin as standard. All enzymatic analyses were performed in duplicate.

\section{Determination of PAHs in water and WSFDO}

Total PAHs and compounds were analyzed in waters from the Macaé River estuary during the sampling period in surface and bottom samples during flood and ebb tides, as well as in the WSFDO used in the laboratory experiments, according to USEPA 8270D (2007) and 3510C (1996), using gaseous chromatography coupled to mass spectrometry (GG/MS). Analyses were performed in triplicate, with the coefficient of variation never higher than $12 \%$, using analytical blanks. The method's limit of detection was $3.00 \mathrm{ng} \mathrm{L}^{-1}$. Accuracy was tested by using the surrogate compounds associated with a sample analysis. The recovery of surrogate compounds perilene- $\mathrm{d}_{12}$ and terphenyl- $\mathrm{d}_{14}$ were of $75 \%$ and $93 \%$, respectively.

\section{Data analysis}

Enzymatic activities ( $\mathrm{mol} \mathrm{min} \mathrm{mg} \mathrm{ptn}^{-1}$ ) in fish obtained from the environment were expressed as means \pm error $(n=72)$ and monthly variations were compared by applying the one-way ANOVA test followed by the Newman-Keuls post hoc test. In the laboratory assay, the comparison of enzymatic activities between exposed $(\mathrm{n}=20)$ and control groups $(n=20)$ and among the different exposed times $(n=6$ for each time) were performed using the one-way ANOVA test followed by the Bonferrone post hoc test. All data were first analyzed regarding normality by the KolmogorovSmirnov test before applying the ANOVA test. Correlations among enzymatic activities and fish weight, size and gender were verified by Pearsons correlation. The differences were considered significant when $P<0.05$. All statistical analyses were performed using the GraphPad Prism software package, version 5.0.

\section{RESULTS AND DISCUSSION}

\section{Field assessment}

GST, CAT and EROD activities determined in the environment fish are displayed in Figure 2. GST levels varied from 1.43 to $6.79 \mu \mathrm{mol} \mathrm{min}{ }^{-1} \mathrm{mg} \mathrm{ptn}{ }^{-1}$ among the individuals with statistically significant peaks in June and

\section{a)}

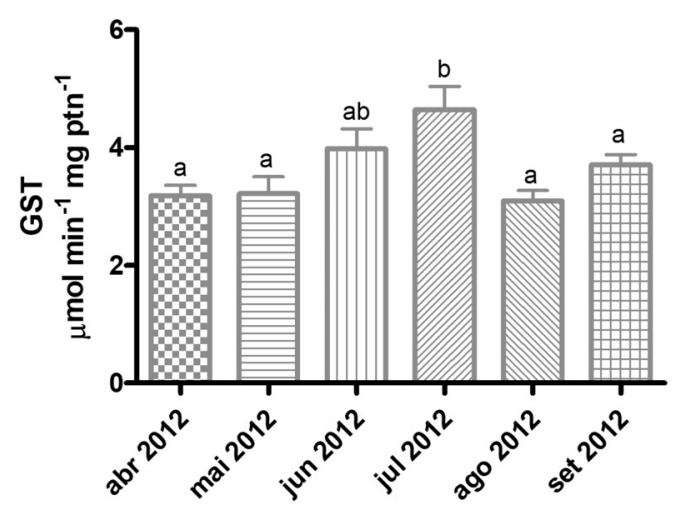

b)

c)
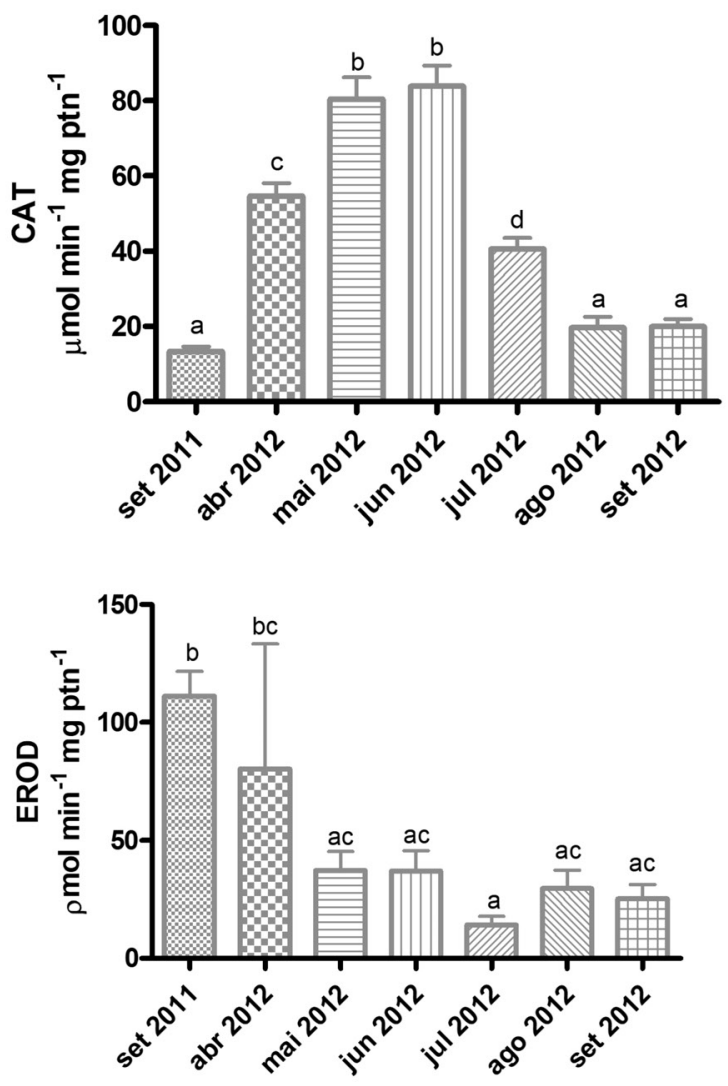

Fig. 2. Monthly variation of GST, CAT and EROD activities in G. genidens from the Macaé River estuary. Different subscript letters show significant differences at $\mathrm{p}<0.05$. 
July 2012 compared to the other months $(P<0.05)$ (Fig. 2a). CAT displayed activities ranging from 8.53 to $109 \mu \mathrm{mol} \mathrm{min}{ }^{-1}$ $\mathrm{mg} \mathrm{ptn}{ }^{-1}$ during the sampling period with statistically higher values in May and June $2012(P<0.05)$ (Fig. 2b). EROD presented activities varying from 1.14 to $167 \mathrm{pmol} \mathrm{min}^{-1} \mathrm{mg}$ $\mathrm{ptn}^{-1}$ among all fish collected, with statistically higher peaks in September 2011 and April $2012(P<0.05)$ (Fig. 2c).

Several reports are found in the literature regarding these enzymes in $G$. genidens from pristine to impacted environments along the Brazilian coast. In general, higher EROD were found in harbored and urbanized regions, while CAT and GST suffered decreases in their activities in polluted areas, mainly estuaries and bays (Wilhelm Filho et al., 2001; Pedrosa et al., 2001; Freire, 2015). However, biomarkers respond to complex environmental conditions, and enzymes may show different behaviors in different situations. For example, CAT was shown to be decreased in polluted areas in winter, but increased during summer, while GST has been reported as increased in polluted sites but similar during winter and summer (Sardi et al., 2016). Considering that such studies and the present work applied similar methodologies for enzymatic determinations, the results obtained herein were compared with values from the literature. The fish from the Macaé River estuary displayed enzymatic activities similar to those found in fish from pristine environments, but the higher peak activities were typical of impacted regions. Compared our results to the literature, the ranged of such enzymes activities for G. genidens from pristine and polluted coastal areas of southern and southeastern Brazil were established for CAT $\left(0.20-109 \mu \mathrm{mol} \mathrm{min}^{-1} \mathrm{mg} \mathrm{ptn}^{-1}\right)$, GST $(1.40-365 \mu \mathrm{mol}$ $\left.\mathrm{min}^{-1} \mathrm{mg} \mathrm{ptn}^{-1}\right)$ and $\operatorname{EROD}\left(1.10-167 \mathrm{pmol} \mathrm{min}^{-1} \mathrm{mg} \mathrm{ptn}^{-1}\right)$.

Regarding seasonality, the literature describes a variable pattern in the activity of these enzymes in G. genidens. Higher EROD and GST activities in winter have been correlated to the behavior of fish species from cold waters, when CYP450 are involved in preparing hormones and steroids for reproduction during the summer (Pedrosa et al., 2001). Furthermore, the absence of seasonality for CAT and total CYP450 has been explained by taking into account the spatial variability induced by pollution status and runoff (Sardi et al., 2016; Azevedo et al., 2013). Although the present study did not sample fish during the summer period, results indicate that CAT enzymatic activity displayed higher peaks in winter (May and June 2012) following GST induction (June and July 2012), similarly to that discussed by Hayes et al. (2005) regarding induction of $\alpha$ and $\mu$ GST classes by oxidative mechanisms. Reactive oxygen species produce inhibitory effects on CYP expression, explaining the low EROD activity during periods of high CAT and GST levels.

The higher EROD observed during September 2011 and April 2012 coincided with the highest PAH concentrations measured in the estuarine waters, suggesting the influence of these organic compounds on the enzymatic mechanisms of the evaluated fish. PAHs in the estuarine waters were detected only during the first two samplings, while the other campaigns presented values below the method limit of detection of 3.00 ng $\mathrm{L}^{-1}$. In September 2011, only naphthalene was reported in surface and bottom waters during the ebb $\left(52.0 \mathrm{ng} \mathrm{L}^{-1}\right.$ and 44.0 ng L ${ }^{-1}$, respectively) and flood (100 and $\left.120 \mathrm{ng} \mathrm{L}^{-1}\right)$ tides. In April 2012, observed phenanthrene was found in bottom waters during flood tide $\left(20.0 \mathrm{ng} \mathrm{L}^{-1}\right)$. The observed PAH concentrations characterized the Macaé River estuary as non-contaminated by these compounds, although maximum values of $120 \mathrm{ng} \mathrm{L}^{-1}$ have also measured at Guanabara Bay (Rio de Janeiro, Brazil), an area considered contaminated by oil derivatives (Meniconi et al., 2002; Vagener et al., 2012). In addition, bottom sediments of the estuary also displayed low total PAH concentrations, typical of slightly contamination areas (maximum of $70.0 \mathrm{ng}$ $\mathrm{g}^{-1}$ ), but with the presence of more diverse PAH compounds, such as phenanthrene, naphthalene, pyrene, chrysene, benzo(b) fluoranthene, benzo(a)pyrene (Molisani et al., 2013b). The reported levels for these compounds are again typical of only slightly contaminated sediments, although, when compared to Taniguchi (2002), concentrations have increased during the last decade in the study area.

EROD activity has been proven an adequate biomarker in field investigations regarding induction by different $\mathrm{PAH}$ compounds (Whyte et al., 2000; Gagnon and Rawson, 2017). However, discrepancies are found in the literature, mainly considering the effects of 3-4 aromatic ringed hydrocarbons. Bols et al. (1999) reported that EROD activity in a rainbow trout liver cell line was not induced by exposure to naphthalene, phenanthrene, anthracene, pyrene, perylene, acenaphthylene, acenaphthene, fluorene, and fluoranthene, but was consistently induced by benzo $[a]$ pyrene and benzo $[b]$ fluoranthene. However, other studies have found that EROD responded to phenanthrene and other PAHs. These results highlight the difference in fish species regarding affinity of the AhR receptor to small-sized molecular compounds, with significant variations between tropical and temperate fish species (Pathiratne and Hemachandra, 2010). Environmental factors have also been demonstrated as affecting the uptake and elimination of compounds such as phenanthrene, higher in fishes in warmer temperatures compared to cold temperatures (Petersen \& Kristensen, 1998). Thus, according to the literature, higher concentrations of phenanthrene and naphthalene in estuarine waters, and possibly other compounds in the sediments, may contribute to the uptake of these pollutants by the demersalbottom feeding G. genidens, inducing EROD activity. The study performed by Pathiratne \& Hemachandra (2010) also proposed that EROD activities in Nile Tilapia were induced by four-ringed aromatic PAHs, such as pyrene and chrysene, which have also been reported in sediments from our study area.

Apart from the possible induction of enzymatic activities by PAHs, responses related to fish biology were also investigated, by correlate body size, weight and gender to enzymatic levels. Individuals ranged from 25.5 to $277 \mathrm{~g}$ in weight and from 13.5 to $31.0 \mathrm{~cm}$ in length. Only CAT showed a statistically significant inverse correlation $(P<0.001)$ with fish weight and size, while gender was not correlated to any evaluated enzymatic activities (Fig. 3, 4, 5). Correlations among enzymatic activities and biometrics data indicate 
that fish morphometric variables influenced the CAT results, but probably caused only minor effects on EROD and GST activities. Antioxidant defense mechanisms can be triggered by temperature, dissolved oxygen, diet and feeding behavior, all of which can lead to higher cellular ROS production in the early life stage of fish (Martínez-Álvarez et al., 2005). The absence of correlations between gender and EROD and GST has also been reported for Genidens genidens from the ItajaíAçu River estuary (Pedrosa et al., 2001).

\section{Laboratory assay}

Figure 6 displays the enzymatic activities of the control and WSFDO exposed fish at the different exposure times.
Only EROD activity presented a statistically significant increase after 24-h exposure to diesel oil when compared to the control group $(P<0.05)$. EROD induction in liver of Poecillia vivipara has been reported after 96-h exposure to $20 \%$ WSFDO, indicating that this oil derivative is capable of inducing detoxification responses in fish (Mattos, 2010). The increase in EROD activity is possibly related to the transcriptional modulation of the CYP1A gene by the AhR receptor, suggesting a cellular biotransformation capacity of PAHs in fish tissues exposed to WSFDO (Timme-Laragy et al., 2007). However, a species of catfish exposed to diesel oil and also biodiesel increased EROD activities but CYP1AmRNA expression was unaltered after exposition (Felício et al., 2015). This lacking agreement was explained by the large periods of a)

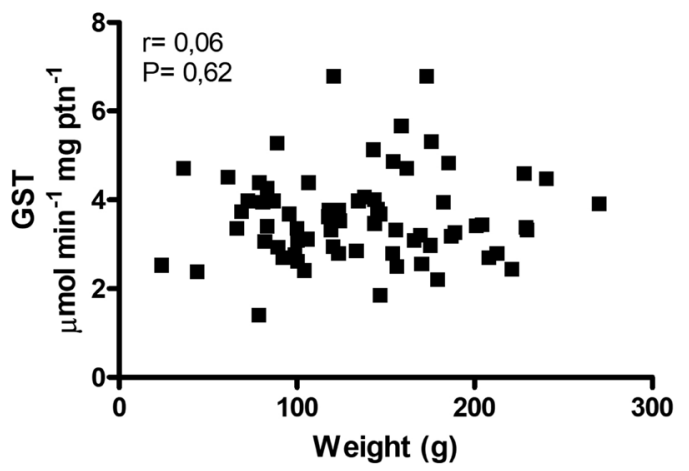

b)

c)
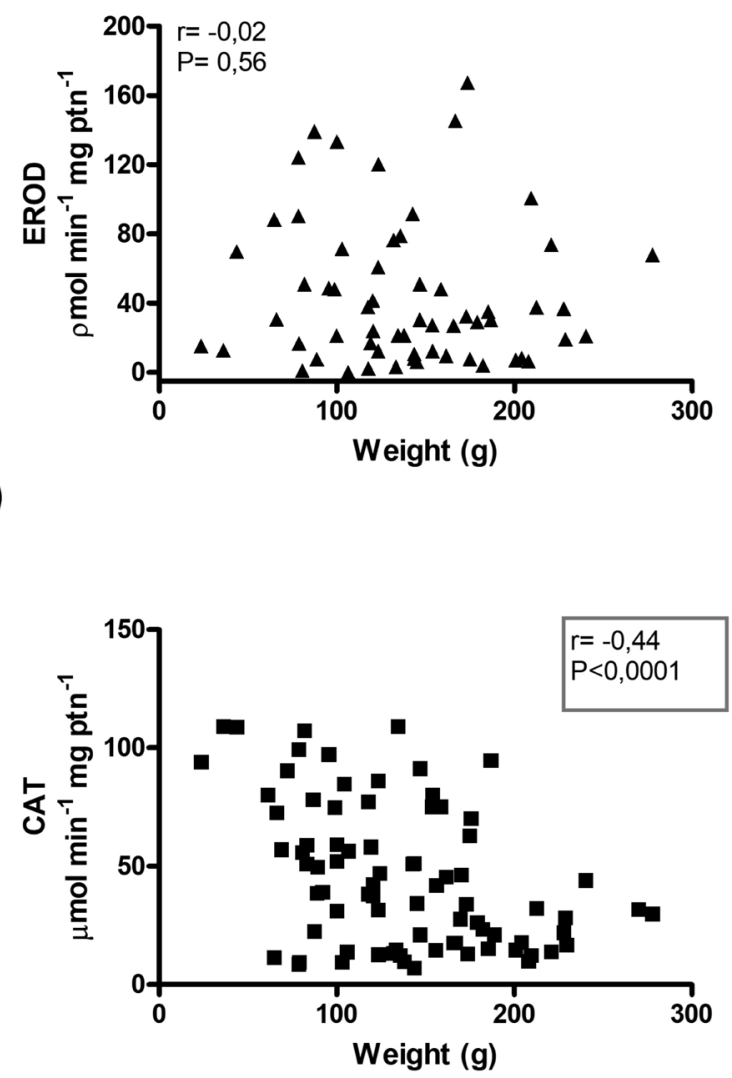

Fig. 3. Correlation among enzymatic activities and fish weight. a)

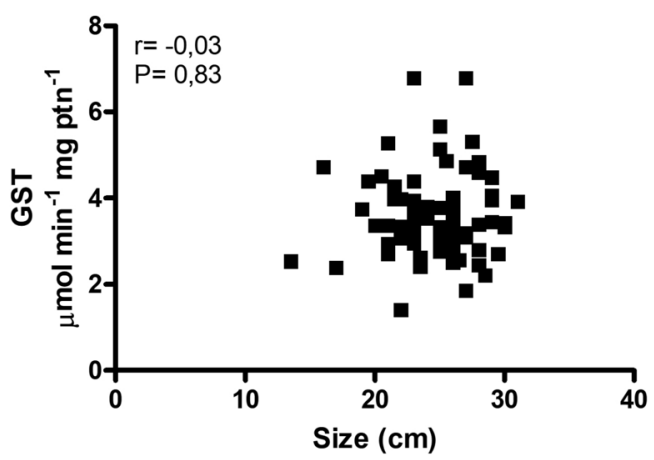

b)

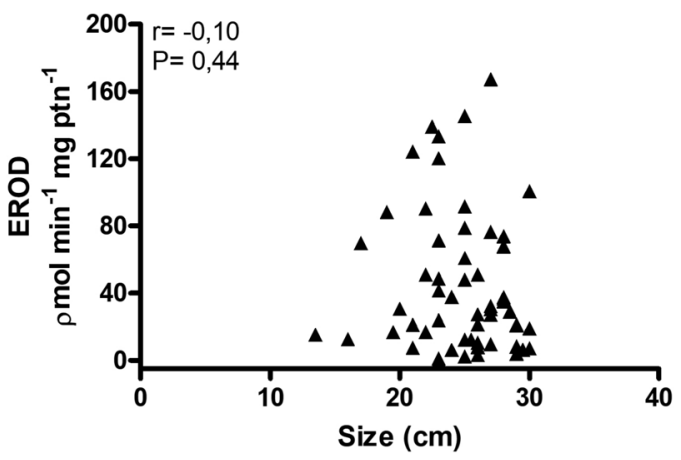

c)

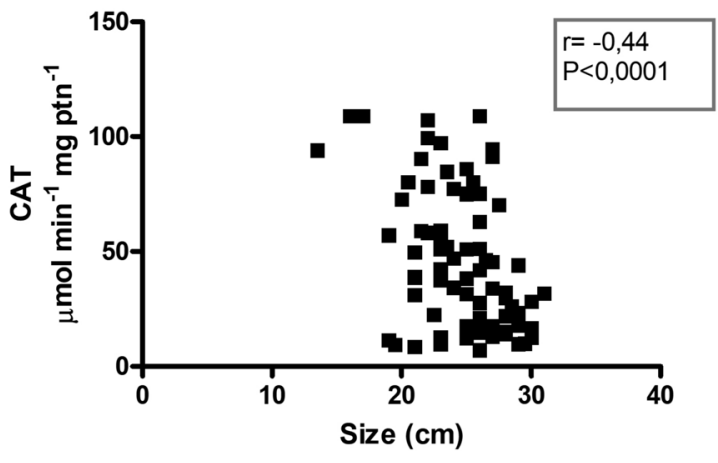

Fig. 4. Correlation among enzymatic activities and fish size. 
A

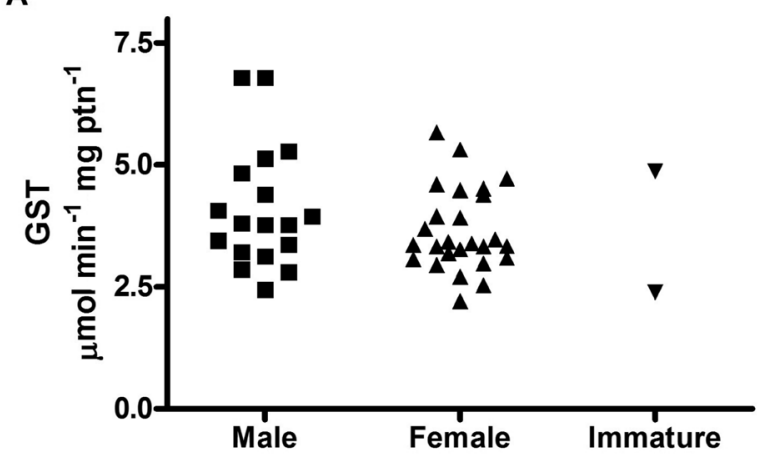

B

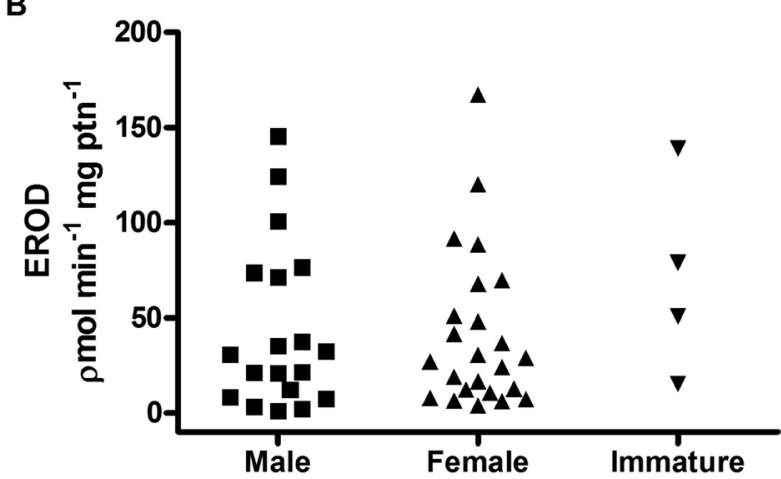

C

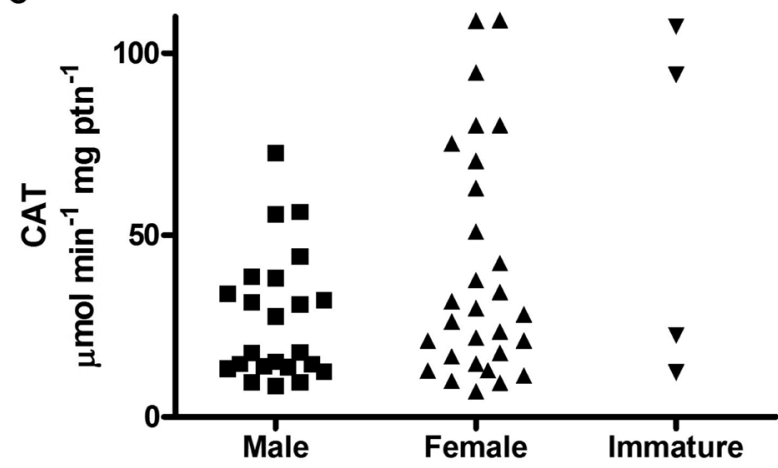

Fig. 5. Analysis of enzymatic activities of fish gender.

exposure to diesel from which CYP1A mRNA is produced following exposure to Ah receptor ligands whereas CYP1A protein and catalytic activities (EROD) remain induced after transcripts return to baseline.

On the other hand, no statistical differences between control and exposed groups were found for GST and CAT. Enzymatic induction by oil derivatives is highly variable in exposition experiments. While some fish species exposed to phenanthrene presented no GST and CAT induction compared to control groups (Oliveira et al., 2008), others species showed induction only for GST when exposed to WSFDO for $96 \mathrm{~h}$ (Mattos, 2010), and for $96 \mathrm{~h}$ and 15 days (Simonato et al., 2008). In the contrary, reduction of GST in liver of Astyanax altiparanae was found after $96 \mathrm{~h}$ exposure to water soluble fraction of gasoline (Bettim et al., 2016). CAT activity, in turn, was not induced in fish exposed to crude oil and WSFDO (Simonato et al., 2008). Generally, antioxidant enzymes are less sensible to pollutants than Phase I and II biotransformation enzymes, however, the fact that CAT was not induced does not exclude reactive oxygen species (ROS) formation, which in turn may be metabolized by glutathione peroxidase (GPx) (Van Der Oost et al., 2003). Compared to the present study and species, the catfish species Pterygoplichtys anisitsi had similar behavior of EROD, CAT and GST when exposed not only to diesel oil, but also to biodiesel which has been produced or mixed to diesel oil in Brazil but has also harmful effects (Felício et al., 2015).

Similar CAT and GST activities observed in the field and laboratory fish suggests that these enzymes are not adequate biomarkers for exposure to this type of oil derivative. On the other hand, EROD induction in exposed fish observed after 24 $\mathrm{h}$, at the same levels of EROD activity reported in fish sampled during September 2011 and April 2012 suggest Genidens genidens responses to this oil derivative and compounds such as PAHs in the evaluated estuary.

Petroleum-derived diesel is composed of about $75 \%$ saturated hydrocarbons (primarily paraffin including $n$, iso and cycloparaffin) and 25\% aromatic hydrocarbons (including naphtalenes and alkylbenzened). The WSFDO prepared for the fish exposure experiment had a total PAHs concentration of $46.0 \mu \mathrm{g} \mathrm{L}^{-1}$, with prevalence of these compounds and their alkylated forms, such as naphtalene, fluoranthene, phenanthrene, dibenzothiophene and pyrene, and minor concentrations of benzo[a]anthracene, chrysene, benzo[a] pyrene, dibenzo[a,h]anthracene and benzo[b]fluorene $(0.48$ $\left.\mu \mathrm{g} \mathrm{L}^{-1}\right)$. PAH concentrations in the WSFDO were an order of magnitude higher than those measured in estuarine waters (maximum $\left.0.12 \mu \mathrm{g} \mathrm{L}^{-1}\right)$ and sediments $\left(0.070 \mu \mathrm{g} \mathrm{L}^{-1}\right)$.

Thus, field and laboratory measurements suggest that EROD in catfish might indicate the presence of PAHs in the water and sediment, but also the influence of additional xenobiotic and/or environmental estuarine conditions. The estuary is highly impacted by untreated sewage and the complex sewage mixtures of unknown composition have also been shown to influence liver EROD activities in African catfish (Mdegela et al., 2010). This complex mixture includes metals, pesticides and PCBs, reported to correlate significantly to fish hepatic EROD in both field and laboratory experiments. Furthermore, environmental factors such as temperature, salinity, dissolved oxygen and others may influence individual metabolic and physiological features, as well as the bioavailability of pollutants through effects on binding, complexation and portioning (Fonseca et al., 2011; Fonseca et al., 2014). Field EROD activities can be related to the usual hormonal function described in the literature, although the Genidens genidens EROD activities determined herein was not correlated to genders (Figure 5). Furthermore, the reproduction period of this species can be variable, commonly occurring during the warmer and rainy months, but has also been reported during other periods (Barbieri et al., 1992) and thus the influence of hormonal function on EROD activity peaks is not expected. 

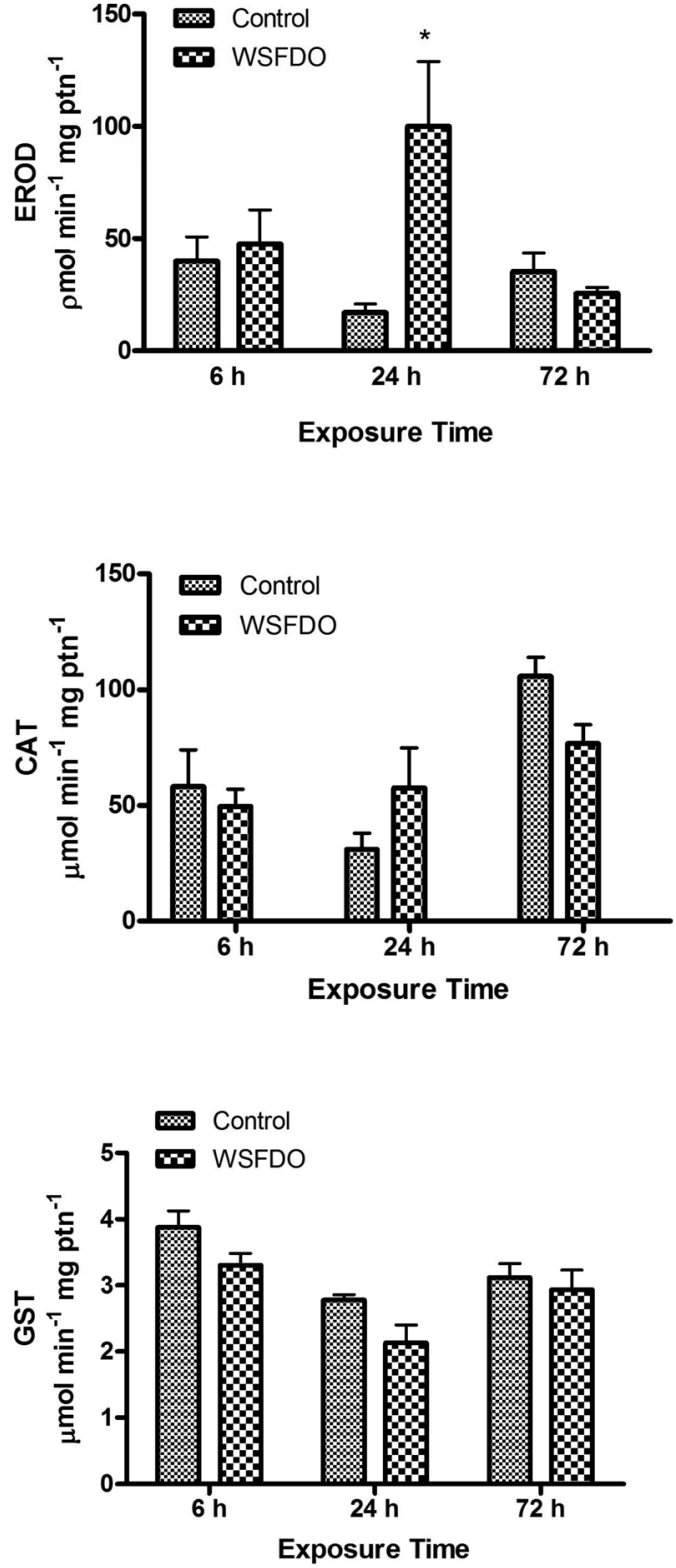

Fig. 6. Hepatic EROD, CAT and GST activities in G. genidens exposed to WSFDO at 6, 24 and $72 \mathrm{~h}$ and control group. Bars represent means and vertical lines the standard error.

* Significant difference of enzymatic activity $(\mathrm{P}<0.05)$.

The literature described comparable EROD enzymatic induction potential for laboratory and field fish species (Gagnon and Rawson, 2017). Such revision also discussed that laboratory data validated with simultaneous field monitoring is considered the most reliable assessment. By reviewing all studies concern EROD induction in Australian fish species, the authors reported only one study with both laboratory and environmental EROD induction assessment using the same species. When both data were available the comparison indicated equivalence on toxic responses which suggest validation of our results for G. genidens from the Macaé river estuary.
Based on EROD analysis, this species showed sensitive for oil contamination in an area under influence of offshore oil exploration, which intensify onshore pollution by oil derivatives and other compounds. Expanding this discussion for the coastal/marine some fish populations, the sensitivity of CYP1A-EROD was in general similar among some coastal fish species, while for the dose-responsiveness by oil derivatives and such compounds, the magnitude responses varied according the species studied (Sanni et al., 2017). Fort other enzymatic biomarkers such as GST and CAT, speciesspecific differences in enzymatic responses to contaminants have been demonstrated for some estuarine species (Fonseca et al., 2014).

\section{CONCLUSIONS}

Field and laboratory enzymes biomarkers in the estuarine/ coastal catfish Genidens genidens complemented estuarine and biological response assessments for oily contamination and overall environmental quality. As a novelty, our study provide CAT, GST and EROD activity range for $G$. genidens from pristine and polluted coastal areas of southern and southeastern Brazil. EROD marked temporally the increase of PAH concentrations in water and probably reflected the presence of EROD-inducing PAH compounds in bottom sediments. Field EROD activities were similar to the laboratory fish responses at 24-h oil diesel exposure, however, differences in PAH content in estuarine waters and WSFDO suggest that other factors other than PAHs induced EROD activity peaks. Concomitant field CAT and GST peaks suggested oxidative stress on fish, but laboratory studies did not relate the enzymes to diesel oil and, therefore, other environmental aspects, including fish weight must have related to the oxidative stress. For contamination assessments, the enzyme data indicated episodic estuarine and fish stress, explained in part by oil derivatives, but also the synergic effects of other xenobiotic(s) and/or environmental conditions. An important contribution of this study is to exemplify that a coastal organism is presenting biochemical responses/stress in a context of increasing onshore activities induced by offshore oil exploration and considering this expanding activity in Brazilian coast, efforts to prevent pollution have to be implemented to protect coastal communities.

\section{ACKNOWLEDGMENTS}

Coordenação de Aperfeiçoamento de Pessoal de Nível Superior (CAPES) provided MS Grant to JN Berenguer. We are grateful for the Prof. Jayme C. Bastos Neto from Departamento de Bioquímica of the Universidade do Estado do Rio de Janeiro to EROD analyses.

\section{REFERENCES}

AEBI, H. 1984. Catalase in vitro. Methods in Enzymol., 105:121126. http://dx.doi.org/10.1016/S0076-6879(84)05016-3 
AZEVEDO, J.S., BRAGA, E.S., ASSIS, H.C.S. \& RIBEIRO, C.A.O. 2013. Biochemical changes in the liver and gill of Cathorops spixii collected seasonally in two Brazilian estuaries under varying influences of anthropogenic activities. Ecotoxicol. Environ. Saf. 96:220-230. http://dx.doi.org /10.1016/j.ecoenv.2013.06.021

BARBIERI, L.R., SANTOS, R.P. \& ANDREATA, J.V. 1992. Reproductive biology of the marine catfish, Genidens genidens (Siluriformes, Ariidae), in the Jacarepaguá lagoon system, Rio de Janeiro, Brasil. Environ. Biol. Fish., 35(2):23-35. http://dx.doi. org/10.1590/S0101-81751999000600017

BETTIM, F.L., GALVAN, G.L., CESTARI, M.M., YAMAMOTO, C.I. \& ASSIS, H.C. 2016. Biochemical responses in freshwater fish after exposure to water-soluble fraction of gasoline. Chemosphere, 144:1467-1475. http://dx.doi.org/10.1016/j. chemosphere.2015.09.109

BOLS, N.C., SCHIRMER, K., JOYCE, E.M., DIXON, D.G., GREENBERG, B.M. \& WHYTE, J.J. 1999. Ability of polycyclic aromatic hydrocarbons to induce 7-Ethoxyresorufin-o -deethylase activity in a trout liver cell line. Ecotoxicol. Environ. Saf., 44(1)118-128. http://dx.doi.org/10.1006/eesa.1999.1808.

BRADFORD, M.M. 1976. A rapid e sensitive method for the quantification of microgram quantities of protein utilizing the principle of protein-dye binding. Anal. Biochem., 72:248-254. http://dx.doi.org/10.1016/0003-2697(76)90527-3

BURKE, M.D., THOMPSON, S., ELCOMBE, C.R., HALPERT, J., HAAPARANTA, T. \& MAYER, R.T. 1985. Ethoxy, penthoxy-, and benzyloxyphenoxazones and homologues: a series of substrates to distinguish between different induced cytochromes P450. Biochem. Pharmacol., 34(18): 3337-3345.

CUNHA BASTOS, V.L.F., RIBEIRO PINTO, L.F., LIMA, L.M. \& CUNHA BASTOS J. 2004. Identification and induction by B-naphthoflavone of CYP1A1 in liver of the neotropical fish Pacu Piaractus mesopotamicus (Characiformes: Characidae). Bull. Environ. Contam. Toxicol., 72: 13-20. http://dx.doi. org/10.1007/s00128-003-0235-6.

DENISONM.S.\&NAGYSR.2003. Activation of the arylhydrocarbon receptor by structurally diverse exogenous and endogenous chemicals. Annu. Rev. Pharmacol. Toxicol., 43:309-334. http:// dx.doi.org/10.1146/annurev.pharmtox.43.100901.135828

FELÍCIO, A.A., PARENTE, T.M., MASCHIO, L.R., NOGUEIRA, L., VENANCIO, L.P.R., REBELO, M.F, SCHLENK, D. \& ALMEIDA, E.A. 2015. Biochemical responses, morphometric changes, genotoxic effects and CYP1A expression in the armored catfish Pterygoplichthys anisitsi after 15 days of exposure to mineral diesel and biodiesel. Ecotoxicol. Environ. Saf., 115: 26-32. http://dx.doi.org/10.1016/j.ecoenv.2015.01.034.

FONSECA, V.F., FRANÇA, S., VASCONCELOS, R.P., SERAFIM, A., COMPANY, R., LOPES, B., BEBIANNO, M.J. \& CABRAL, H.N. 2011. Short-term variability of multiple biomarker response in fish from estuaries: Influence of environmental dynamics. Mar. Environ. Res., 72(4): 172-178. http://dx.doi.org/10.1016/j. marenvres.2011.08.001

FONSECA, V.F., VASCONCELOS, R.P., FRANÇA, S., SERAFIM, A., LOPES, B., COMPANY, R., BEBIANNO, M.J., COSTA, M.J., \& CABRAL, H.N. 2011. Modeling fish biological responses to contaminants and natural variability in estuaries. Mar. Environ. Res., 96:45-55. http://dx.doi.org/10.1016/j. marenvres.2013.10.011

FREIRE, A. 2015. Avaliação dos efeitos da contaminação por hidrocarbonetos policíclicos aromáticos em peixes (Genidens genidens) do litoral do Estado do Rio de Janeiro. PhD Thesis. Universidade Federal Fluminense, Niterói, 112p.

GAGNON, M.M. \& RAWSON C.A. 2017. Bioindicator species for EROD activity measurements: A review with Australian fish as a case study. Ecol. Indic. 73: 166-180. http://dx.doi.org/10.1016/j. ecolind.2016.09.015

HAYES, J.D., FLANAGAN, J.U. \& JOWSEY, I.R. 2005. Glutathione transferases. Annu. Rev. Pharmacol. Toxicol., 45:51-88. http:// dx.doi.org/10.1146/annurev.pharmtox.45.120403.095857

KEEN, J.H., HABIG, W.H. \& JAKOBY, W.B. 1976. Mechanism for several activities of the glutathione S-transferases. J. Biol. Chem., 251(20): 6183-6188.

KRISTENSEN, P. \& PETERSEN, G. 1998. Bioaccumulation of lipophilic substances in fish early life stages. Environ. Toxicol. Chem., 17(7): 1385-1395. http://dx.doi.org/10.1002/ etc. 5620170724

MARTÍNEZ-ÁLVAREZ, R.M., MORALES, A.E. \& SANZ, A. 2005. Antioxidant defenses in fish: biotic and abiotic factors. Rev. Fish Biol., 15(1-2): 75-88. http://dx.doi.org/10.1007/ s11160-005-7846-4

MATTOS, J.J. 2010. Respostas bioquímicas e moleculares no peixe Poecilia vivipara exposto à fração de óleo diesel acomodada em água. MSc. Dissertation, Universidade Federal de Santa Catarina, Florianópolis, 120p.

MDEGELA, R., BRAATHEN, M., MOSHA, R.D., SKAARE, J.U. \& SANDVIK, M. 2010. Assessment of pollution in sewage ponds using biomarker responses in wild African sharptooth catfish (Clarias gariepinus) in Tanzania. Ecotoxicology, 19(4):722734. http://dx.doi.org/10.1007/s10646-009-0449-4

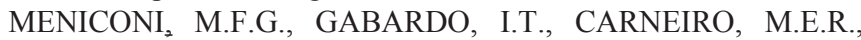
BARBANTI, S.M., SILVA, G.C. \& MASSONE, C.G. 2002. Brazilian oil spills chemical characterization - case studies. Environ. Forensics, 3(3-4): 303-321. http://dx.doi.org/10.1006/ enfo.2002.0101

MISHIMA, M. \& TANJI, S. 1981. Distribuição geográfica dos bagres marinhos (Osteichthyes, Ariidae) no complexo lagunar de Cananéia $\left(25^{\circ} \mathrm{S}, 48^{\circ} \mathrm{W}\right)$. Bol. Inst. Pesca, 9: 131-40.

MOLISANI, M.M., ESTEVES, F.A., REZENDE, C.E. \& LACERDA, L.D. 2013a. Emissões naturais e antrópicas de nitrogênio, fósforo e metais para a bacia do rio Macaé (Macaé, RJ, Brasil) sob influência das atividades de exploração de petróleo e gás na Bacia de Campos. Quím. Nova, 36(1): 27-33. http://dx.doi.org/10.1590/S0100-40422013000100006.

MOLISANI, M.M., COSTA, R.N., CUNHA, P., REZENDE, C.E., FERREIRA, M.I.P. \& ESTEVES, F.A. 2013b. Acute Toxicity Bioassay with the Amphipod, Grandidierella bonnieroides $S$. After Exposure to Sediments from an Urban Estuary (Macaé River Estuary, RJ, Brazil). Bull. Environ. Contam. Toxicol., 90(1): 79-84. http://dx.doi.org/10.1007/s00128-012-0871-9

NICODEM, D.E., FERNANDES, M.C.Z., GUEDES, C.L.B. \& CORREA, R.J. 1997. Photochemical processes and the environmental impact of petroleum spills. Biogeochemistry, 39(2):121-138. http://dx.doi.org/10.1023/A:1005802027380

NRC, National Research Council, Committee on Oil in the Sea. 2003. Oil in the sea III: Inputs, fates, and effects. National Academy Press, Washington, DC.

OLIVEIRA, M., PACHECO, M. \& SANTOS, M.A. 2008. Organ specific antioxidant responses in golden grey mullet (Liza aurata) following a short-term exposure to phenanthrene. Sci. Total Environ., 396(1): 70-78. http://dx.doi.org/10.1016/j. scitotenv.2008.02.012

PATHIRATNE, A. \& HEMACHANDRA, C.K. 2010. Modulation of ethoxyresorufin O-deethylase and glutathione S-transferase activities in Nile tilapia (Oreochromis niloticus) by polycyclic aromatic hydrocarbons containing two to four rings: implications in biomonitoring aquatic pollution. Ecotoxicology, 19(6):10121018. http://dx.doi.org/10.1007/s10646-010-0482-3

PAYNE, J.F. 1976. Field evaluation of benzopyrene hydroxylase 
induction as a monitor for marine petroleum pollution. Science, 191(4230): 945-946. http://dx.doi.org/10.1126/science.1251203

PEDROSA, R., GEREMIAS, R., SILVA, M., FIGNA, V., LOCATELLI, C. \& FILHO, D. 2001. Biomonitoramento do estuário do rio Itagaí-Açu (SC) utilizando a indução do citocromo P4501A e glutationa S-transferase de bagres como biomarcadores. In: MORAES R, CRAPEZ M, PFEIFFER W, FARINA M, BAINY A, TEIXEIRA V. (eds) Efeitos de poluentes em organismos marinhos, Villi Press, pp. 35-48.

PETERSEN, G.I. \& KRISTENSE, P. 1998. Bioaccumulation of lipophilic substances in fish early life stages. Environ. Toxicol., 17(7):1385-1395. http://dx.doi.org/10.1002/etc.5620170724

SANNI, S., BJÖRKBLOM, C., JONSSON, H., GODAL, B.F., LIEWENBORG, B., LYNG, E. \& PAMPANIN, D.M. 2017. Biomarker quantification in fish exposed to crude oil as input to species sensitivity distributions and threshold values for environmental monitoring. Mar. Environ. Res. 125:10-24. http:// dx.doi.org/10.1016/j.marenvres.2016.12.002

SANTIAGO, I.U., MOLISANI, M.M., NUDI, A.H., SCOFIELD, A.L., WAGENER, A.L.R. \& LIMAVERDE FILHO, A. 2016. Hydrocarbons and trace metals in mussels in the Macaé coast: Preliminary assessment for a coastal zone under influence of offshore oil field exploration in southeastern Brazil. Mar. Pollut. Bull., 103(1-2):349-353. http://dx.doi.org/10.1016/j. marpolbul.2015.12.034

SARDI, A.E., RENAUD P.E., LANA, P.C. \& CAMUS, L. 2016. Baseline levels of oxidative stress biomarkers in species from a subtropical estuarine system (Paranaguá Bay, southern Brazil). Mar. Pollut. Bull., 113(1-2):496-508. http://dx.doi.org/10.1016/j. marpolbul.2016.08.014

SCHMIDT, T.C., MARTINS, I.A., REIGADA, A.L. \& DIAS, J. F. 2008. Taxocenose de bagres marinhos (Siluriformes, Ariidae) da região estuarina de São Vicente, SP, Brasil. Biota Neotrop., 8(4):73-81. http://dx.doi.org/10.1590/S167606032008000400006

SIMONATO, J.D., GUEDES, C.L.B. \& MARTINEZ, C.B.R. 2008. Biochemical, physiological, and histological changes in the neotropical fish Prochilodus lineatus exposed to diesel oil. Ecotoxicol. Environ. Saf., 69(1): 112-120. http://dx.doi. org/10.1016/j.ecoenv.2007.01.012

SINGER, M.M., AURAND, M.M.D., BRAGIN, G.E., CLARK,
J.R., COELHO, G.M., SOWBY, M.L. \& TJEERDEMA, R.S. 2000. Standardization of the preparation and quantitation of water-accommodated fractions of petroleum for toxicity testing. Mar. Pollut. Bull, 40(11):1007-1016. http://dx.doi.org/10.1016/ S0025-326X(00)00045-X

TANIGUCHI, S. 2002. Avaliação da contaminação por hidrocarbonetos e organoclorados em diferentes compartimentos do ambiente marinho do Estado do Rio de Janeiro. PhD thesis, Universidade de São Paulo, São Paulo, 161p.

TIMME-LARAGY, A.R., COCKMAN, C.J., COLE, W.M. \& DI GIULIO, R.T. 2007. Synergistic induction of AHR regulated genes in developmental toxicity from co-exposure to two model PAHs in zebrafish. Aquat. Toxicol., 85(4):241-250. http://dx.doi. org/10.1016/j.aquatox.2007.09.005

USEPA (Environmental Protection Agency), 2007. Semi volatile organic compounds by gas chromatography/mass spectrometry (GC/MS), Test methods for evaluating solid waste, physical/ chemical methods, EPA/SW-846 on-line, US, Washington, DC.

USEPA (Environmental Protection Agency), 1996. Separatory funnel liquid-liquid extraction. Test methods for evaluating solid waste, physical/chemical methods, EPA/SW-846 on-line, Washington, DC.

VAN DER OOST, R., BEYER, J. \& VERMEULAN, N.P.E. 2003. Fish bioaccumulation and biomarkers in environmental risk assessment: a review. Environ. Toxicol. Pharmacol., 13(2):57149. http://dx.doi.org/10.1016/S1382-6689(02)00126-6

WAGENER, A.L.R., MENICONI, M.F.G., HAMACHER, C., FARIAS, C.O., DA SILVA, G.C., GABARDO, I.T. \& SCOFIELD, A.L. 2012. Hydrocarbons in sediments of a chronically contaminated bay: the challenge of source assignment. Mar. Pollut. Bull., 64(2): 284-294. http://dx.doi. org/10.1016/j.marpolbul.2011.11.018

WHYTE, J.J., JUNG, R.E., SCHMITT, C.J. \& TILLITT, D.E. 2000. Ethoxyresorufin-O-deethylase (EROD) activity in fish as a biomarker of chemical exposure. Crit. Rev. Toxicol., 30(4): $347-$ 570. http://dx.doi.org/10.1080/10408440091159239

WILHELM FILHO, D., TORRES, M.A., TESTA, C.P., TRIBESS, T.B., GEREMIAS, R., PEDROSA, R.C. \& HOSTIM-SILVA, M. 2001. Estresse oxidativo em bagres Genidens Genidens (Ariidae) do litoral de Santa Catarina. In: MORAES, R. B. C. $\mathrm{DE}$ et al. (ed). Efeitos de poluentes em organismos marinhos. São Paulo: Arte \& Ciência Villipress, pp. 49-64. 